\title{
Copper(II) and Amylin Analogues: A Complicated Relationship
}

\author{
Mawadda Alghrably," Dorota Dudek," Abdul-Hamid Emwas, Łukasz Jaremko, Mariusz Jaremko,* \\ and Magdalena Rowińska-Żyrek*
}

Cite This: https://dx.doi.org/10.1021/acs.inorgchem.9b03498

Read Online

ACCESS | W W Metrics \& More | 国 Article Recommendations | st Supporting Information

ABSTRACT: Protein aggregation has attracted substantial interest because of its role in causing many serious illnesses, such as neurodegenerative diseases and type II diabetes. Recent studies have shown that protein aggregation can be prevented by forming metal ion complexes with a target protein, which affects their conformation in solution and their physical properties, such as aggregation. Thus, understanding the interactions between aggregating molecules and bioactive metal ions such as $\mathrm{Cu}^{2+}$ is beneficial for new drug discovery. Pramlintide, a synthetic peptide drug, and its natural counterpart rat amylin are known to be resistant to aggregation because of the presence of proline residues, which are usually $\beta$-sheet "breakers" within their amino acid

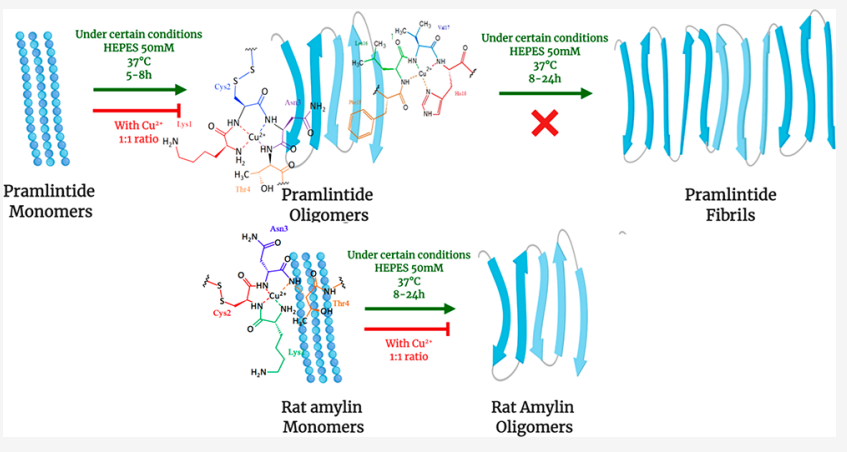
sequence. Here, we investigate the $\mathrm{Cu}^{2+}$ coordination properties of pramlintide and rat amylin using nuclear magnetic resonance, circular dichroism, electron paramagnetic resonance, ultraviolet-visible spectroscopy, potentiometry, and mass spectrometry. We test the influence of $\mathrm{Cu}^{2+}$ on the aggregation properties of these amylin analogues with thioflavin $\mathrm{T}$ assays. We find that both peptides form stable complexes with $\mathrm{Cu}^{2+}$ with similar affinities at a 1:1 ratio. The $\mathrm{N}$-termini of both peptides are involved in $\mathrm{Cu}^{2+}$ binding; His 18 imidazole is an equally attractive binding site in the case of pramlintide. Our results show that $\mathrm{Cu}^{2+}$ ions influence the aggregation of pramlintide, but not that of rat amylin.

\section{INTRODUCTION}

Amylin, islet amyloid polypeptide, and IAPP are all names for a specific 37-amino acid peptide hormone that has an amidated C-terminus and a disulfide bridge between Cys2 and Cys7. This amino acid is secreted from pancreatic $\beta$-cells into the bloodstream along with insulin. ${ }^{1}$ The effects of amylin are complementary to those of insulin, which is the primary hormone that regulates and maintains blood glucose levels. ${ }^{2,3}$ Insulin was the first peptide hormone discovered and is used successfully to treat diabetic patients. ${ }^{4-6}$ Human IAPP (hIAPP) plays a role in glycemic regulation by slowing gastric emptying and promoting satiety, thereby preventing postprandial spikes in blood glucose levels. However, it cannot be used as a drug for diabetic treatment because of its tendency to misfold and form cytotoxic fibrils, ${ }^{7}$ which have been strongly associated with $\beta$-cell degeneration in type 2 diabetes mellitus (T2DM).$^{8-10}$ This limitation led to the development of an amylin synthetic analogue, pramlintide, to overcome the physicochemical properties of aggregation and toxicity. The amino acid sequence of pramlintide is characterized by the substitution of Ala25, Ser28, and Ser29 in the hIAPP sequence with prolines ${ }^{11}$ (Figure 1), and these substitutions make pramlintide very suitable for use as a drug. ${ }^{12}$ Pramlintide is commonly used in the United States in insulin-resistant patients $^{13}$ and has also recently been shown to have antimicrobial properties. ${ }^{14}$
Human amylin: KCNTATCATQRLANFLVHSSNNFGAILSSTNVGSNTY-NH Rat amylin: KCNTATCATQRLANFLVRSSNNLGPVLPPTNVGSNTY-NH Pramlintide: KCNTATCATQRLANFLVHSSNNFGPILPPTNVGSNTY-NH

Figure 1. Primary sequence of amylin analogues. Differences among human amylin, rat amylin, and pramlintide primary structures are colored red.

Rat IAPP (rIAPP) is a nontoxic and nonamyloidogenic peptide variant of human amylin. rIAPP differs from hIAPP in its amino acid sequence in six amino acid residues, having three prolines in the same positions as pramlintide, F23L and I26V substitutions, and, most importantly, an H18R substitution, which eliminates one of the possible strong $\mathrm{Cu}^{2+}$ binding sites ${ }^{15}$ (Figure 1 ).

The metabolism of copper(II) is associated with pathological amyloid formation in diabetes. ${ }^{16}$ Previous studies have recognized the importance of the interaction of amylin with $\mathrm{Cu}^{2+}$ and $\mathrm{Zn}^{2+}$; this interaction is associated with the

Received: December 1, 2019 
aggregation of amylin and the modulation of the proteolytic activity of IAPP-degrading enzymes; ${ }^{17-22}$ however, there are some conflicting findings about the impact of $\mathrm{Cu}^{2+}$ on human amylin, related to both increased and decreased copper(II)mediated amylin cytotoxicity. ${ }^{23-25}$

The easy release and absorption of one electron in $\mathrm{Cu}^{2+}$ makes it particularly useful in oxidation-reduction reactions and free radical scavenging. ${ }^{26-28}$ At physiological $\mathrm{pH}$ (7.4), there is little or no free $\mathrm{Cu}^{2+}$ in solution, especially if chelating agents are available within its proximity. ${ }^{21}$ In the neutral-pH range, $\mathrm{Cu}^{2+}$ can bind to the rIAPP peptide fragment ${ }^{19} \mathrm{SSNN}^{22}-{ }^{29}$ If the $\mathrm{N}$-terminal amino group is available for binding, it serves as an anchoring site for $\mathrm{Cu}^{2+} .{ }^{30}$ However, even if this group is acetylated, the ${ }^{19} \mathrm{SSNN}^{22}$ - sequence can still form stable complexes with $\mathrm{Cu}^{2+}$, where the amide nitrogens are the binding sites, and the asparagine side chains additionally stabilize the square planar $\mathrm{Cu}^{2+}$ complex. ${ }^{29,31}$

Sanchez-Lopez et al. showed that in several amylin fragments, $\mathrm{Cu}^{2+}$ binds to the imidazole $\mathrm{N} 1$ of His18 and to the deprotonated amides of Ser19 and Ser20, which is, from a thermodynamical point of view, not the most common type of coordination. In such cases, a seven-membered chelate ring is formed instead of the thermodynamically preferred sixmembered ring that would have formed if the amides in the $\mathrm{N}$-terminal direction had participated in binding. ${ }^{32}$ The role of His 18 in $\mathrm{Cu}^{2+}$ binding has also been shown in an amylin ${ }_{1-19}$ fragment $^{33}$ and in an $\mathrm{R} 18 \mathrm{H}$ substituted analogue of rat amylin. $^{34}$ The lack of His18 in rat amylin makes it not susceptible to aggregation. ${ }^{15}$

\section{EXPERIMENTAL SECTION}

Synthesis. C-Protected disulfide-bridged pramlintide (KCNTATCATQRLANFLVHSSNNFGPILPPTNVGSNTY-NH ${ }_{2}$ ) and C-protected disulfide-bridged rat amylin (KCNTATCATQRLANFLVRSSNNLGPVLPPTNVGSNTY-NH $\mathrm{N}_{2}$ ) were purchased from KareBayBiochem (certified purity of $99.30 \%$ ) and used as received. We checked their purity potentiometrically. The $\mathrm{Cu}\left(\mathrm{NO}_{3}\right)_{2}$ was an extra pure product (Sigma-Aldrich); we determined the concentrations of their stock solutions by ICP-MS. The carbonate-free stock solution of $0.1 \mathrm{M} \mathrm{NaOH}$ was purchased from Merck and then potentiometrically standardized with potassium hydrogen phthalate.

Mass Spectrometry. We obtained high-resolution mass spectra from a BrukerQ-FTMS spectrometer (BrukerDaltonik, Bremen, Germany), equipped with an Apollo II electrospray ionization source with an ion funnel. We operated the mass spectrometer in positive ion mode. We set the instrumental parameters as follows: scan range of $\mathrm{m} / z 300-3000$, dry gas ofnitrogen, temperature of $170^{\circ} \mathrm{C}$, and ion energy of $5 \mathrm{eV}$. The capillary voltage was optimized to the highest signal-to-noise ratio that was observed for a voltage of $4500 \mathrm{~V}$. The small changes in voltage $( \pm 500 \mathrm{~V})$ did not significantly affect the optimized spectra. We prepared the samples $\left(1: 1 \mathrm{Cu}^{2+}\right.$ :ligand stoichiometry, $\left.[\text { ligand }]_{\text {tot }}=10^{-4} \mathrm{M}\right)$ in a $1: 1$ acetonitrile/water mixture at $\mathrm{pH}$ 7.4. The variation in the solvent composition down to $5 \%$ acetonitrile is expected not to change the species composition significantly. We infused the sample at a flow rate of $3 \mu \mathrm{L} / \mathrm{min}$. We calibrated the instrument externally with the Tunemix mixture (BrukerDaltonik) in the quadratic regression mode. We processed the data using the Bruker Compass DataAnalysis 4.0 program. The mass accuracy for the calibration was better than 5 ppm, enabling, together with the true isotopic pattern (using SigmaFit), an unambiguous confirmation of the elemental composition of the obtained complex.

Potentiometry. We calculated the stability constants for proton and $\mathrm{Cu}^{2+}$ complexes from titration curves carried out over the $\mathrm{pH}$ range of $2-11$ at $298 \mathrm{~K}$ with an ionic strength of $0.1 \mathrm{M}\left(\mathrm{KNO}_{3}\right)$ using a total volume of $3 \mathrm{~cm}^{3}$. We performed the potentiometric titrations using a Dosimat 665 Metrohm titrator connected to a Metrohm 691 $\mathrm{pH}$-meter and a Mettler Toledo InLab microglass electrode. The thermostabilized glass cell was equipped with a magnetic stirring system, a microburet delivery tube, and an inlet-outlet tube for argon. We titrated the solutions with $0.1 \mathrm{M}$ carbonate-free $\mathrm{NaOH}$. We calibrated the electrodes for hydrogen ion concentration by titrating $\mathrm{HNO}_{3}$ with $\mathrm{NaOH}$ under the same experimental conditions that are described above. We determined the purities and the exact concentrations of the ligand solutions by the Gran method. ${ }^{35}$ The ligand concentration was $0.5 \mathrm{mM}$, and the $\mathrm{Cu}^{2+}$ :ligand ratio was $1: 1$.

We used the HYPERQUAD 2006 and SUPERQUAD programs for the stability constant calculations. ${ }^{36,37}$ We computed the standard deviations with HYPERQUAD 2006, which refer to random errors only. We computed the speciation and competition diagrams with the HYSS program. ${ }^{38}$

Nuclear Magnetic Resonance (NMR) Spectroscopy. Pramlintide was dissolved in $500 \mu \mathrm{L}$ of $100 \% \mathrm{D}_{2} \mathrm{O}$, and rIAPP was dissolved in $800 \mu \mathrm{L}$ of $100 \% \mathrm{D}_{2} \mathrm{O}$, both to a concentration of $1 \mathrm{mM}$. We manually adjusted the $\mathrm{pH}$ electrode readout to 5.10 (which corresponded to $\mathrm{pH} 5.51$ according to Covington et al. ${ }^{39}$ ) with a stock solution of $0.1 \mathrm{M} \mathrm{NaOD}$ in $100 \% \mathrm{D}_{2} \mathrm{O}$. We used these samples for ${ }^{1} \mathrm{H}$ and ${ }^{13} \mathrm{C}$ resonance assignments. We then manually adjusted the $\mathrm{pH}$ to 7.4 with a $0.1 \mathrm{M} \mathrm{NaOD}$ stock solution in $100 \% \mathrm{D}_{2} \mathrm{O}$ and then adjusted the assignments of ${ }^{1} \mathrm{H}$ and ${ }^{13} \mathrm{C}$ resonances to the new conditions. To assign $\mathrm{HN}$ resonances, we prepared samples of the studied peptides in an analogous way but in a 90:10 (v/v) $\mathrm{H}_{2} \mathrm{O} / \mathrm{D}_{2} \mathrm{O}$ solution, and after assignment, we manually corrected the $\mathrm{pH}$ of the solution to 7.4 using the $0.1 \mathrm{M} \mathrm{NaOH}$ stock solution in $100 \% \mathrm{H}_{2} \mathrm{O}$. We performed all NMR experiments on the 600 and $700 \mathrm{MHz}$ Bruker spectrometer at $25{ }^{\circ} \mathrm{C}$. The NMR data were processed by NMRPipe ${ }^{40}$ and analyzed with Sparky ${ }^{41}$ software. Analysis of the ${ }^{1} \mathrm{H},{ }^{13} \mathrm{C}$, and ${ }^{15} \mathrm{~N}$ resonances for the two peptides was carried out by application of a standard procedure ${ }^{42}$ based on the inspection of the two-dimensional (2D) homonuclear ${ }^{1} \mathrm{H}-{ }^{1} \mathrm{H}$ TOCSY (with mixing times of 10 and $80 \mathrm{~ms}$ ), 2D ${ }^{1} \mathrm{H}-{ }^{1} \mathrm{H}$ ROESY, and $2 \mathrm{D}{ }^{1} \mathrm{H}-{ }^{1} \mathrm{H}$ NOESY (with mixing times of 300 and $500 \mathrm{~ms}$ ) supported by the natural abundance $2 \mathrm{D}{ }^{1} \mathrm{H}-{ }^{15} \mathrm{~N}$ HSQC and $2 \mathrm{D}{ }^{1} \mathrm{H}-{ }^{13} \mathrm{C}$ HSQC experiments (separately tuned for the aliphatic and aromatic regions).

The addition of paramagnetic $\mathrm{Cu}^{2+}$ to the solution caused signal broadening because of the paramagnetic contribution of $\mathrm{Cu}^{2+}$ to the spin-lattice relaxation $\left(R_{1}\right)$ rates of ${ }^{1} \mathrm{H}$ protons. ${ }^{42,43}$ To decipher the residues involved in the $\mathrm{Cu}^{2+}$ coordination for the studied peptides, we monitored the binding of $\mathrm{Cu}^{2+}$ to the pramlintide and rIAPP peptides by NMR. We performed $\mathrm{Cu}^{2+}$ measurements through the stepwise addition of a $\mathrm{Cu}\left(\mathrm{NO}_{3}\right)_{2}$ stock solution $[0.01 \mathrm{M}$ in $100 \%$ $\mathrm{D}_{2} \mathrm{O}$ for the samples in $100 \% \mathrm{D}_{2} \mathrm{O}$ and in $100 \% \mathrm{H}_{2} \mathrm{O}$ for the samples in a $90: 10(\mathrm{v} / \mathrm{v}) \mathrm{H}_{2} \mathrm{O} / \mathrm{D}_{2} \mathrm{O}$ mixture] to the solution of peptides, giving peptide: $\mathrm{Cu}^{2+}$ molar ratios of 1:0.02, 1:0.04, 1:0.08, and 1:0.16. For each peptide: $\mathrm{Cu}^{2+}$ ratio, we checked the $\mathrm{pH}$ and adjusted it to 7.4 (when necessary) with the $0.1 \mathrm{M} \mathrm{NaOD}$ stock solution. We recorded the same set of one-dimensional and 2D NMR spectra that were recorded for the free peptides for the complexes with $\mathrm{Cu}^{2+}$.

Electron Paramagnetic Resonance (EPR) Spectroscopy. We used EPR spectroscopy to study the paramagnetic transition metals $^{44-49}$ and organic radicals. ${ }^{50-56}$ Specifically, we utilized EPR spectroscopy to study the interactions between the $\mathrm{Cu}^{2+}$ ions and amylin analogues, where we measured the $g$ values and the hyperfine coupling values for free ions and the peptide samples as titrated with a $\mathrm{Cu}^{2+}$ solution. We recorded the EPR spectra using an X-band continuous wave Bruker EMX PLUS spectrometer equipped with a standard resonator for high-sensitivity CW-EPR (Bruker BioSpin, Rheinstetten, Germany). For comparative analysis, we carried out all experiments under the same instrumental parameters. We recorded the spectra at $100 \mathrm{~K}$ using the Bruker nitrogen setup. The microwave power was set to $0.625 \mathrm{~mW}$ with a $5 \mathrm{G}$ modulation amplitude and a $100 \mathrm{kHz}$ modulation frequency. We used the Bruker Xenon software (Bruker BioSpin) to collect data and for postprocessing.

Ultraviolet-Visible (UV-vis) and Circular Dichroism (CD) Spectroscopy. We recorded the absorption UV-vis spectra on a Varian Cary300 Bio spectrophotometer, in the range of $200-800 \mathrm{~nm}$, 
Table 1. Potentiometric and Spectroscopic Data for $\mathrm{Cu}(\mathrm{II})$ Complexes with Rat Amylin and Pramlintide ${ }^{a}$

\begin{tabular}{|c|c|c|c|c|c|c|c|c|c|}
\hline \multirow[b]{2}{*}{ species } & \multicolumn{2}{|c|}{ potentiometry } & \multicolumn{2}{|c|}{ UV-vis } & \multicolumn{2}{|r|}{$\mathrm{CD}$} & \multicolumn{3}{|c|}{ EPR } \\
\hline & $\log \beta$ & $\mathrm{p} K_{\mathrm{a}}$ & $\lambda(\mathrm{nm})$ & $\varepsilon\left(\mathrm{M}^{-1} \mathrm{~cm}^{-1}\right)$ & $\lambda(\mathrm{nm})$ & $\Delta \varepsilon\left(\mathrm{M}^{-1} \mathrm{~cm}^{-1}\right)$ & $g_{\|}$ & $g_{\perp}$ & $A_{\|}(\mathrm{G})$ \\
\hline & & & & Rat Amylin & & & & & \\
\hline \multicolumn{10}{|l|}{ ligand } \\
\hline $\mathrm{LH}$ & $10.20(4)$ & $10.20(\mathrm{~K})$ & & & & & & & \\
\hline $\mathrm{LH}_{2}$ & $19.69(3)$ & $9.49(\mathrm{Y})$ & & & & & & & \\
\hline $\mathrm{LH}_{3}$ & $26.82(6)$ & $7.13(\mathrm{~N}-\mathrm{t})$ & & & & & & & \\
\hline \multicolumn{10}{|c|}{$\mathrm{Cu}(\mathrm{II})$ complex } \\
\hline \multirow[t]{5}{*}{$\mathrm{CuHL}$} & 19.25 & 5.23 & 557 & 96.79 & 588.2 & -0.28 & 2.20 & 2.08 & 124 \\
\hline & & & & & 506 & 0.30 & & & \\
\hline & & & & & 318.5 & 0.27 & & & \\
\hline & & & & & 278.6 & -1.09 & & & \\
\hline & & & & & 251.7 & 0.56 & & & \\
\hline \multirow[t]{6}{*}{$\mathrm{CuL}$} & 14.02 & 8.08 & 550 & 138.29 & 571.1 & -0.52 & 2.22 & 2.05 & 198 \\
\hline & & & & & 478.8 & 0,46 & & & \\
\hline & & & & & 316.4 & 0.55 & & & \\
\hline & & & & & 280.5 & -0.92 & & & \\
\hline & & & & & 254.7 & 1.24 & & & \\
\hline & & & & & 235.6 & -8.61 & & & \\
\hline \multirow[t]{5}{*}{$\mathrm{CuH}_{-1} \mathrm{~L}$} & 5.94 & 9.44 & 542 & 138.21 & 566.1 & -0.71 & 2.26 & 2.04 & 194 \\
\hline & & & & & 487.5 & 0.44 & & & \\
\hline & & & & & 312.3 & 0.59 & & & \\
\hline & & & & & 281.9 & -0.73 & & & \\
\hline & & & & & 253.6 & 1.19 & & & \\
\hline \multirow[t]{5}{*}{$\mathrm{CuH}_{-2} \mathrm{~L}$} & -3.50 & 9.76 & 524 & 182.4 & 560.4 & -0.90 & & & \\
\hline & & & & & 479.6 & 0.52 & & & \\
\hline & & & & & 310.6 & 0.63 & & & \\
\hline & & & & & 279.8 & -0.51 & & & \\
\hline & & & & & 253.3 & 1.24 & & & \\
\hline \multirow[t]{6}{*}{$\mathrm{CuH}_{-3} \mathrm{~L}$} & -13.26 & & 525 & 145.94 & 557.5 & -0.98 & & & \\
\hline & & & & & 479 & 0.51 & & & \\
\hline & & & & & 305.4 & 0.67 & & & \\
\hline & & & & & 280.1 & -0.39 & & & \\
\hline & & & & & 252 & 1.79 & & & \\
\hline & & & & Pramlintide & & & & & \\
\hline \multicolumn{10}{|l|}{ ligand } \\
\hline LH & $10.32(1)$ & $10.32(\mathrm{~K})$ & & & & & & & \\
\hline $\mathrm{LH}_{2}$ & $19.98(1)$ & $9.67(\mathrm{Y})$ & & & & & & & \\
\hline $\mathrm{LH}_{3}$ & $27.51(1)$ & $7.53(\mathrm{~N}-\mathrm{t})$ & & & & & & & \\
\hline $\mathrm{LH}_{4}$ & $33.31(1)$ & $5.79(\mathrm{H})$ & & & & & & & \\
\hline \multicolumn{10}{|c|}{$\mathrm{Cu}(\mathrm{II})$ complex } \\
\hline $\mathrm{CuH}_{2} \mathrm{~L}$ & 26.08 & 5.04 & & minor & & minor & & & \\
\hline $\mathrm{CuHL}$ & 21.04 & 6.74 & 564 & 143.28 & 610.4 & -0.32 & 2.27 & 2.08 & 139 \\
\hline & & & & & 502.1 & 0.08 & & & \\
\hline & & & & & 329.9 & 0.14 & & & \\
\hline & & & & & 285.6 & -0.54 & & & \\
\hline & & & & & 255 & 0.29 & & & \\
\hline & & & & & 234 & -9.19 & & & \\
\hline $\mathrm{CuL}$ & 14.3 & 8.59 & 558 & 243.33 & 599.1 & -0.54 & 2.217 & 2.05 & 192 \\
\hline & & & & & 502.1 & 0.16 & & & \\
\hline & & & & & 325.2 & 0.19 & & & \\
\hline & & & & & 290.5 & -0.31 & & & \\
\hline & & & & & 255.1 & 1.46 & & & \\
\hline $\mathrm{CuH}_{-1} \mathrm{~L}$ & 5.7 & 9.59 & 541 & 280.76 & 564.8 & -0.68 & 2.20 & 2.04 & 195 \\
\hline & & & & & 492.8 & 0.09 & & & \\
\hline & & & & & 318.3 & 0.29 & & & \\
\hline & & & & & 289.5 & -0.22 & & & \\
\hline & & & & & 257.5 & 2.10 & & & \\
\hline $\mathrm{CuH}_{-2} \mathrm{~L}$ & -3.89 & 10.14 & 528 & 279.5 & 563.7 & -0.87 & & & \\
\hline & & & & & 483 & 0.06 & & & \\
\hline & & & & & 320.4 & 0.33 & & & \\
\hline
\end{tabular}




\section{Table 1. continued}

\begin{tabular}{|c|c|c|c|c|c|c|c|c|c|}
\hline \multirow[b]{2}{*}{ species } & \multicolumn{2}{|c|}{ potentiometry } & \multicolumn{2}{|c|}{ UV-vis } & \multicolumn{2}{|r|}{$\mathrm{CD}$} & \multicolumn{3}{|c|}{ EPR } \\
\hline & $\log \beta$ & $\mathrm{p} K_{\mathrm{a}}$ & $\lambda(\mathrm{nm})$ & $\varepsilon\left(\mathrm{M}^{-1} \mathrm{~cm}^{-1}\right)$ & $\lambda(\mathrm{nm})$ & $\Delta \varepsilon\left(\mathrm{M}^{-1} \mathrm{~cm}^{-1}\right)$ & $g_{\|}$ & $g_{\perp}$ & $A_{\|}(\mathrm{G})$ \\
\hline \multirow{8}{*}{$\mathrm{CuH}_{-3} \mathrm{~L}$} & \multirow{8}{*}{-14} & & \multirow{8}{*}{520} & Pramlintide & & & & & \\
\hline & & & & \multirow{7}{*}{286.75} & 288.4 & -0.21 & & & \\
\hline & & & & & 257.1 & 2.08 & & & \\
\hline & & & & & 561.7 & -0.96 & & & \\
\hline & & & & & 481.7 & 0.11 & & & \\
\hline & & & & & 321.8 & 0.19 & & & \\
\hline & & & & & 289.8 & -0.29 & & & \\
\hline & & & & & 257.8 & 2.11 & & & \\
\hline
\end{tabular}

${ }^{a_{1}}$ The errors in EPR parameters were estimated to be \pm 0.0002 .

using a quartz cuvette with an optical path of $1 \mathrm{~cm}$. A Jasco J-1500CD spectrometer recorded the CD spectra in the range of $200-800 \mathrm{~nm}$, using a quartz cuvette with an optical path of $1 \mathrm{~cm}$ in the visible and near-UV range. We prepared the $\mathrm{Cu}^{2+}$-peptide complexes in a water solution of $\mathrm{HNO}_{3}$ at an ionic strength of $0.1 \mathrm{~mol} \mathrm{dm}^{-3}\left(\mathrm{KNO}_{3}\right)$. The concentrations of the solutions used for spectroscopic studies were similar to those employed in the potentiometric experiments. The metal:ligand ratio was $1: 1$. We adjusted the $\mathrm{pH}$ with the appropriate amounts of $\mathrm{HNO}_{3}$ and $\mathrm{NaOH}$ solutions. We calculated the UV-vis and $\mathrm{CD}$ spectroscopic parameters from the spectra obtained at the $\mathrm{pH}$ values corresponding to the maximum concentration of each particular species, based on distribution diagrams.

Thioflavin T (ThT) Assay. We conducted the amyloid aggregation kinetics (either rIAPP or pramlintide) in a 96-well flat-bottom black plate (Corning 3915) sealed with transparent film (Duck Brand Crystal Clear Tape, Avon, $\mathrm{OH})$. All experiments were conducted at $25^{\circ} \mathrm{C}$, containing $20 \mu \mathrm{M}$ thioflavin $\mathrm{T}$ (ThT), $2 \%$ (v/v) DMSO (final concentration), and a $50 \mathrm{mM}$ HEPES buffer solution ( $\mathrm{pH}$ 7.4), using a final amylin concentration of $38.4 \mu \mathrm{M}$ (from a $10 \mathrm{mg} / \mathrm{mL}$ stock in $100 \%$ DMSO), in a final volume of $200 \mu \mathrm{L}$. These conditions are widely accepted for the study of the aggregation properties of amylin. ${ }^{57-59}$ Therefore, we applied an analogous procedure to study the amylin analogues. We performed the aggregation assay on a Synergy 2 Multi-Mode Microplate with excitation set at 485/20 nm and emission at $528 / 20 \mathrm{~nm}$ with a gain equal to 35 . We collected measurements by $50 \%$ top reading each $10 \mathrm{~min}$ after a $3 \mathrm{~s}$ vibration.

\section{RESULTS AND DISCUSSION}

We studied the $\mathrm{Cu}^{2+}$ complexes with rat amylin and pramlintide by mass spectrometry, potentiometry, the ThT assay, and UV-vis, CD, NMR, and EPR spectroscopy. The mass spectrometric measurements provided information about the stoichiometry of the formed complexes. We determined the precise stability constants and $\mathrm{pH}$-dependent species distribution diagrams by potentiometric titrations. The spectroscopic results allowed us to deduce the mode of binding of the $\mathrm{Cu}^{2+}$ complexes formed with the studied peptides and the geometry of the formed species. The NMR spectra recorded in the presence and absence of the metal ions indicated the precise metal binding sites.

Stoichiometry of the Binding of $\mathrm{Cu}^{2+}$ with Amylin. ESI-MS spectrometry confirmed that both peptides form only mononuclear complexes with copper(II) ions. In the $\mathrm{Cu}^{2+}-$ rat amylin mass spectra (Figure S1), the prevailing signals correspond to the free ligand $(m / z 980.5, z=4+)$, its sodium adducts that contain one sodium atmo $(m / z 986.0, z=4+)$ and two sodium atoms $(m / z$ 991.5, $z=4+)$, an equimolar copper(II) complex $(m / z$ 996.2, $z=4+)$, and its sodium adduct $(m / z 1001.2, z=4+)$. In the case of pramlintide, in the mass spectra (Figure S2), we can observe signals that can be assigned to the free ligand $(m / z 988.0, z=4+)$, the dehydrated ligand $(m / z$ 982.5, $z=4+)$, adducts with sodium $(m / z$ 992.0, $z$ $=4+)$ and potassium $(m / z$ 997.7, $z=4+)$ atoms, the copper(II) complex $(m / z 1003.2, z=4+)$, and its sodium $(m /$ $z$ 1009.0, $z=4+)$ and potassium adducts $(m / z 1012.9, z=4+)$. In both cases, the simulated isotopic patterns of copper(II) complexes are in a perfect agreement with the experimental ones.

Protonation Equilibria. Rat amylin (KCNTATCATQRLANFLVRSSNNLGPVLPPTNVGSNTY- $\mathrm{NH}_{2}$ ) behaves as an $\mathrm{LH}_{3}$ acid, with the deprotonating groups corresponding to the $\mathrm{N}$-terminal amine group, tyrosine side chain, and lysine side chain with $\mathrm{p} K_{\mathrm{a}}$ values of $7.13,9.49$, and 10.20 , respectively (Table 1). The cysteine groups are bridged with a disulfide bond, and the C-terminal tyrosine is amidated, as in wild type rat amylin. We previously discussed protonation constants of pramlintide (KCNTATCATQRLANFLVHSSNNFGPILPPTNVGSNTY- $\left.\mathrm{NH}_{2}\right),{ }^{60}$ showing that it behaves as an $\mathrm{LH}_{4}$ acid, with the deprotonating groups corresponding to the histidine imidazole, the $\mathrm{N}$-terminal amine group, and the tyrosine and lysine side chain groups, with $\mathrm{p} K_{\mathrm{a}}$ values of 5.79, 7.53, 9.67, and 10.32, respectively.

$\mathrm{Cu}^{2+}$-rIAPP Complex. The coordination of $\mathrm{Cu}^{2+}$ with rat amylin begins at $\mathrm{pH} 4$ (Figure 2A). The maximum of the $\mathrm{CuHL}$ form occurs around $\mathrm{pH} 5.5$, with the $\mathrm{N}$-terminal amine group and the closest amide involved in coordination, resulting in a pronounced CT band near $290 \mathrm{~nm}$ and a d-d transition at $588 \mathrm{~nm}$ in the CD spectra, respectively (Figure S3). The spectra indicate that the complex starts to adopt a square planar geometry, with the amide nitrogen being involved in the coordination. The $\mathrm{CD}$ band near $278 \mathrm{~nm}$ suggests that the $\mathrm{N}$ terminal amine takes part in the binding. The next two deprotonations lead to the formation of the $\mathrm{CuL}$ and $\mathrm{CuH}_{-1} \mathrm{~L}$ forms, with $\mathrm{p} K_{\mathrm{a}}$ values of 8.08 and 9.44, respectively. Because we observe a blue shift and an increase in intensity in CD [from 588 to $566 \mathrm{~nm}$ (Table 1 and Figure S3)] and UV-vis [from 557 to $542 \mathrm{~nm}$ (Table 1 and Figure S4)], we can assume that two more amides are involved in coordination, resulting in an $\left(\mathrm{NH}_{2}, 3 \mathrm{~N}_{\mathrm{am}}\right)$ binding mode (Figure 3). Further support comes from EPR data. Both $g_{\|}$and the hyperfine coupling constant parameter $\left(A_{\|}\right)$, which equal 2.22 and $198 \mathrm{G}$, respectively (Table 1 ), indicate a $3 \mathrm{~N}$ coordination mode for $\mathrm{CuL}$ species and a $4 \mathrm{~N}$ coordination mode for $\mathrm{CuH}_{-1} \mathrm{~L}$, with a $g_{\|}$of 2.26 and an $A_{\|}$of 194. We also must take into account the fact that the $\mathrm{CuLH}_{-1}$ species may involve not only a pure amide coordination but also a partial deprotonation of the noncoordinating tyrosine chain, as indicated by a quite high wavelength at which a UV-vis maximum for these species is observed [ $542 \mathrm{~nm}$ instead of a typical value of $520 \mathrm{~nm}$; a 
A

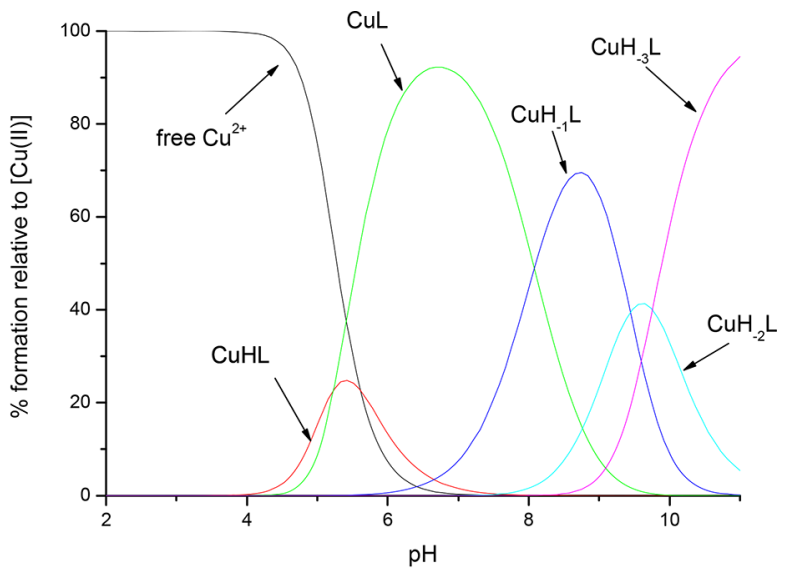

B

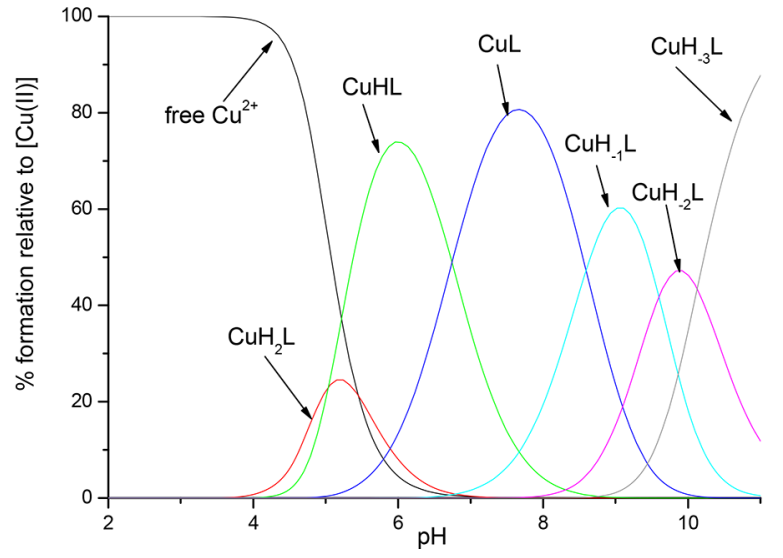

Figure 2. Distribution diagram for the formation of $\mathrm{Cu}^{2+}$ complexes with (A) rat amylin and (B) pramlintide, at $25{ }^{\circ} \mathrm{C}$ and $I=0.1 \mathrm{M}$. $\left[\mathrm{M}^{2+}\right]=0.45 \times 10^{-3} \mathrm{M}$; M:L molar ratio of 1:1.

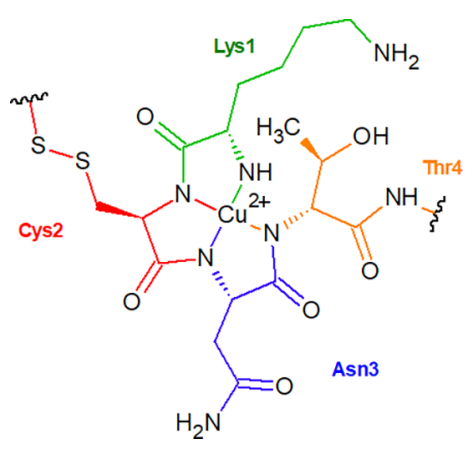

Figure 3. Proposed coordination mode for the $\mathrm{Cu}^{2+}-$ rat amylin complex above $\mathrm{pH} 8$.

similar phenomenon could also be possible in the $\mathrm{Cu}(\mathrm{II})-$ pramlintide species discussed below].

In the CuL species, at $\mathrm{pH} 7.4$, on the NMR spectra, almost all residues are evenly and very weakly affected, with the exception of three of the initial residues, Lys1, Cys2, and Asn3, and two latter residues, Leu16 and Val17, whose intensity decreases to $\sim 80 \%$ of their initial value after the addition of 0.08 equiv of $\mathrm{Cu}^{2+}$ (Figure 4A). The two remaining deprotonations ( $\mathrm{p} \mathrm{K}_{\mathrm{a}} \mathrm{s}$ of 9.44 and 9.76) lead to $\mathrm{CuH}_{-2} \mathrm{~L}$ and $\mathrm{CuH}_{-3} \mathrm{~L}$ forms and are related to the deprotonation of the unbound tyrosine and lysine side chains and do not change the coordination sphere.
A

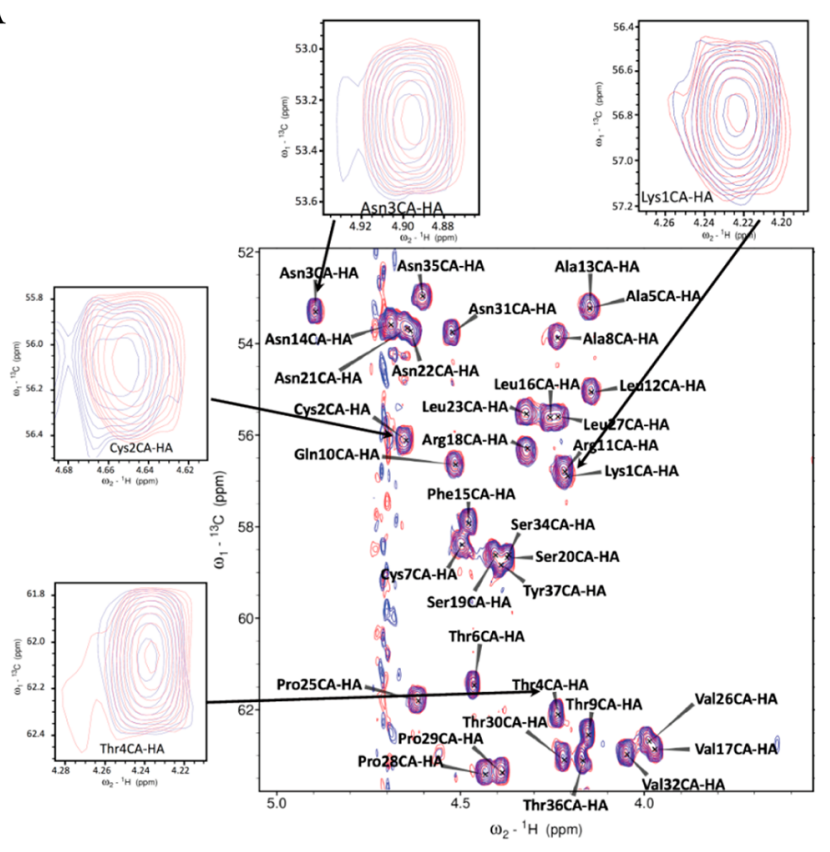

B

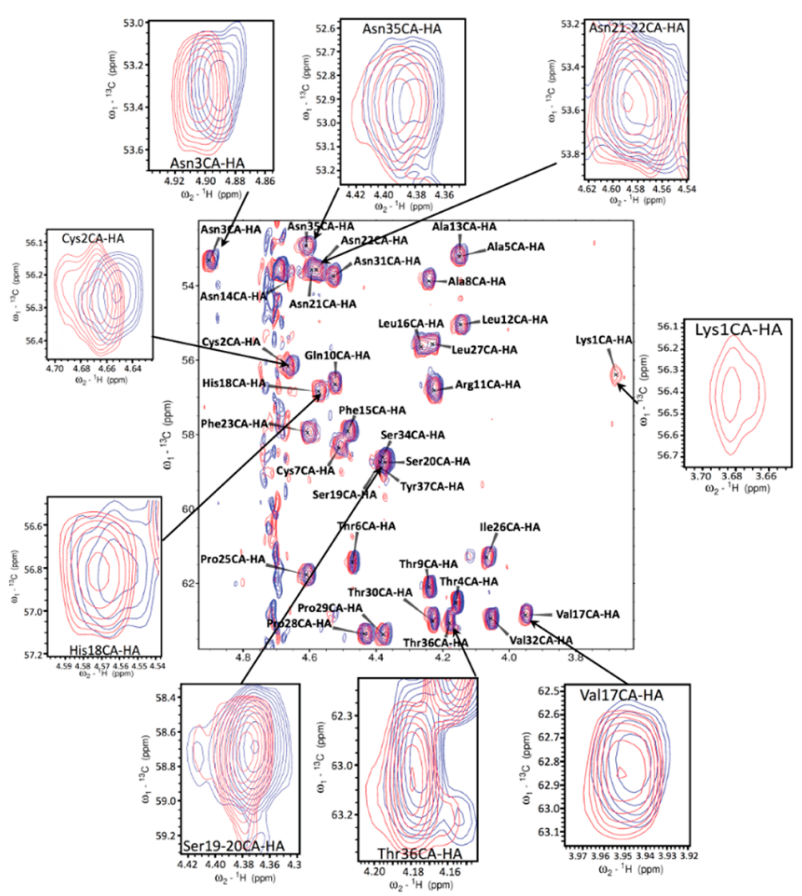

Figure 4. $2 \mathrm{D}{ }^{1} \mathrm{H}-{ }^{13} \mathrm{C} \mathrm{HSQC}$ spectrum $(\mathrm{C} \alpha-\mathrm{H} \alpha$ region) of (A) rat amylin and (B) pramlintide in the absence (red contours) and presence (blue contours) of 0.08 equiv of $\mathrm{Cu}^{2+}$ at $\mathrm{pH}$ 7.4.

$\mathrm{Cu}^{2+}-$ Pramlintide Complex. The coordination of $\mathrm{Cu}^{2+}$ to pramlintide begins around $\mathrm{pH} 4$ (Figure $2 \mathrm{~B}$ ). In the $\mathrm{CuH}_{2} \mathrm{~L}$ complex form, the His 18 imidazole and the N-terminal amine groups are involved in the coordination sphere, resulting in an $\left[\mathrm{N}_{\mathrm{im}}, \mathrm{NH}_{2}\right]$ type of coordination. His 18 is directly involved in the binding, which is proven by the prominent intensity decrease and the signal broadening of the imidazole ring signals of His 18 determined by NMR. Also at $\mathrm{pH}$ 5.5, immediately after the dissolution of the peptide and the addition of $\mathrm{Cu}^{2+}$, we observe signal broadening in the $\mathrm{N}$ - 

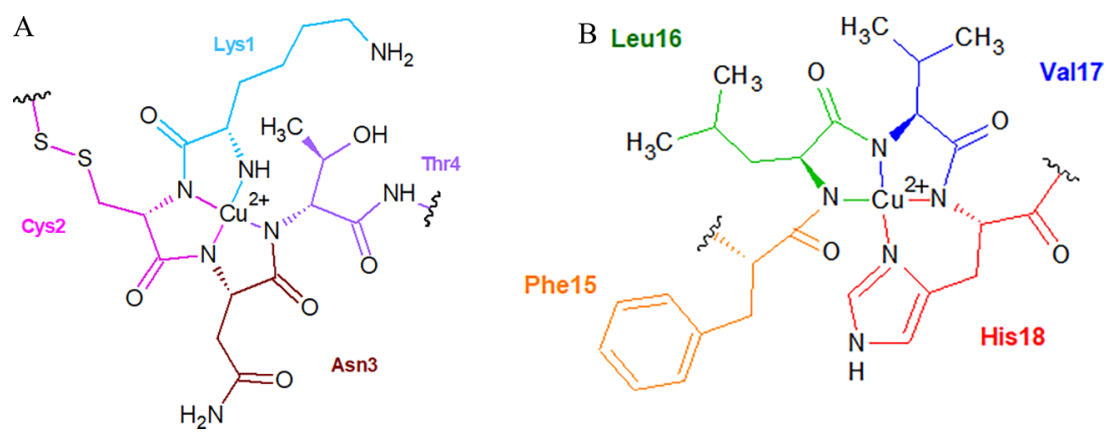

Figure 5. Proposed coordination mode for the $\mathrm{Cu}^{2+}$-pramlintide complex. NMR spectroscopy confirms that at $\mathrm{pH} 7.4 \mathrm{Cu}^{2+}$ may be coordinated to either (A) the N-terminal amine and three neighboring amide nitrogens (toward the C-terminus) or (B) the His18 imidazole nitrogen and three neighboring amide nitrogens (toward the $\mathrm{N}$-terminus).
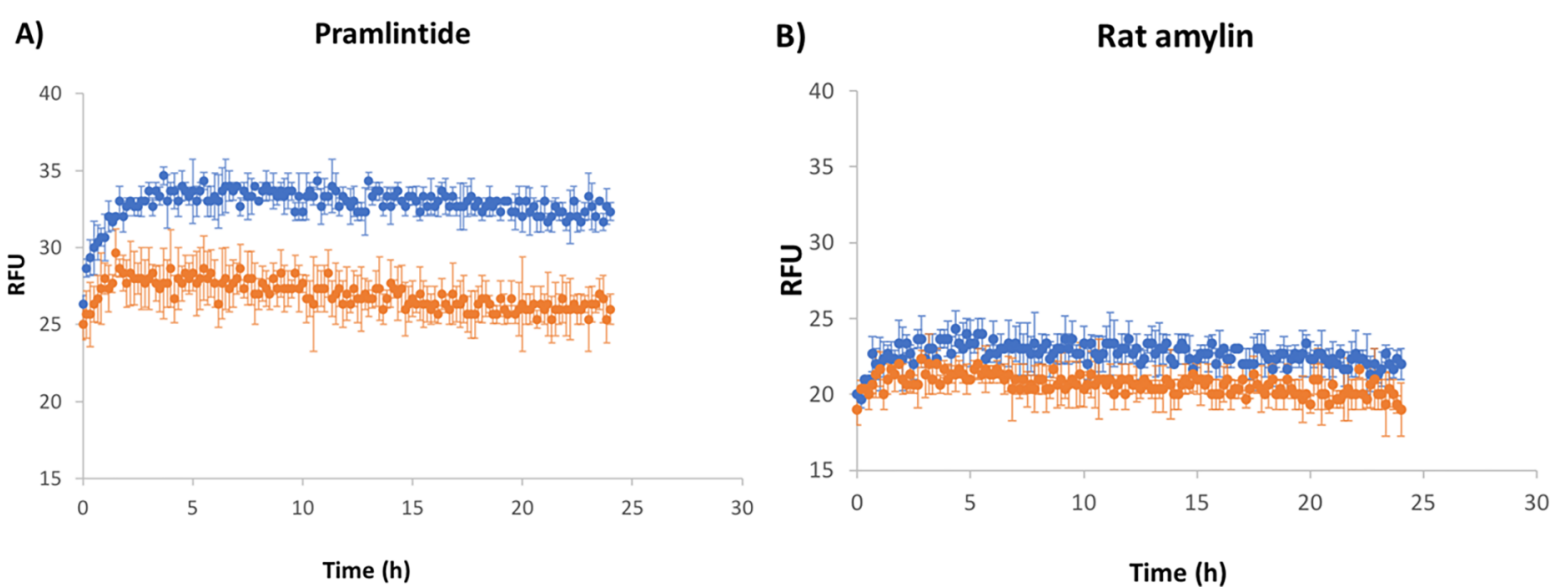

Figure 6. Effect of $\mathrm{Cu}^{2+}$ on pramlintide and rat amylin aggregation in a HEPES-buffered solution: (A) pramlintide and (B) rat amylin. Amylin analogues $(38.4 \mu \mathrm{M})$ were subjected to aggregation at $25^{\circ} \mathrm{C}$ in the presence of $20 \mu \mathrm{M}$ ThT and $50 \mathrm{mM}$ HEPES.

terminal amino acids (Lys1 and Cys2) in the $\mathrm{C} \alpha$ region of the ${ }^{1} \mathrm{H}-{ }^{13} \mathrm{C}$ HSQC spectrum (Figure S5).

The loss of one proton leads to the formation of the CuHL complex, with a maximum at $\mathrm{pH} 6$, in which a $\mathrm{d}-\mathrm{d}$ transition band at $\sim 610 \mathrm{~nm}$ starts to appear on the CD spectra (Figure S6) and the band near $564 \mathrm{~nm}$ is visible in the UV-vis spectra (Figure S7). These spectroscopic results suggest that the amide group is engaged in coordination at this $\mathrm{pH}$. The next two deprotonations lead to the formation of $\mathrm{CuL}$ and $\mathrm{CuH}_{-1} \mathrm{~L}$ complexes. We observe a significant blue shift in the CD (from 610 to $599 \mathrm{~nm}$ and then to $564 \mathrm{~nm}$ ) and in the UV-vis spectra (from 564 to $558 \mathrm{~nm}$ and then to $541 \mathrm{~nm}$ ) (Figures S6 and S7). These shifts indicate the participation of two more amide nitrogens in the metal coordination. At this point, the $\mathrm{CD}$ spectra of the $\mathrm{Cu}^{2+}$-pramlintide complex are very similar to those of the $\mathrm{Cu}^{2+}$-rat amylin complex (Figures S3 and S6). EPR parameters $\left[g_{\|}=2.217\right.$ and $A_{\|}=192 \mathrm{G}$ for $\mathrm{CuL}$ species, and $g_{\|}=2.20$ and $A_{\|}=195 \mathrm{G}$ for $\mathrm{CuH}_{-1} \mathrm{~L}$ (Table 1)] are indicative of the involvement of three and four nitrogen atoms in the coordination sphere. Most likely, an equilibrium between two $\mathrm{Cu}^{2+}$-pramlintide forms is reached: the first form, in which the N-terminal amine and the adjacent amides are bound to $\mathrm{Cu}^{2+}$ [because in the NMR spectra, at $\mathrm{pH} 7.4$, we observe a signal broadening of $\mathrm{N}$-terminal residues, especially in the $\mathrm{C} \alpha$ region of Lys1, Cys2, and Asn 3 in the ${ }^{1} \mathrm{H}-{ }^{13} \mathrm{C}$ HSQC spectrum (Figure 4B)], and the second, in which the His 18 imidazole and the preceding amides are involved in the binding [because also the signal broadening in the $\mathrm{C} \alpha$ region of Val17 and Leu16 is observed in the NMR spectra, at $\mathrm{pH} 7.4$
(Figure 4B)]. Both of the proposed $\mathrm{Cu}^{2+}$ coordination modes are presented at Figure 5. The loss of two additional protons $\left(\mathrm{p} K_{\mathrm{a}} \mathrm{s}\right.$ of 9.59 and 10.14 ) at a very basic $\mathrm{pH}$ is associated with the deprotonation of tyrosine and lysine and has no impact on the coordination mode.

The constant exchange between $\mathrm{Cu}^{2+}$ and the peptides is indicated by the decrease in the signal intensity of the $\mathrm{C} \alpha-\mathrm{H} \alpha$ peaks for residues such as Ala5-Ala8 and Thr30-Thr36 for pramlintide (and also Thr6-Ala8 and Ser29-Thr36 for rIAPP), which are neither directly involved in permanent $\mathrm{Cu}^{2+}$ binding nor located in the sequential proximity of the residues involved in $\mathrm{Cu}^{2+}$ coordination (Figure 4). The observed decrease in cross-peak intensity for the residues mentioned above can be attributed to these regions being in the spatial proximity to the mentioned sites and the $\mathrm{Cu}^{2+}$ ions being in constant exchange between the peptide molecules that are in quantitative excess.

Effect of $\mathrm{Cu}^{2+}$ on the Aggregation Kinetics of Amylin Analogues. We evaluated the aggregation of pramlintide and rat amylin in the presence and absence of $\mathrm{Cu}^{2+}$ ions to examine the effect of $\mathrm{Cu}^{2+}$ on the two peptides (Figure 6). We carried out the tests in HEPES buffer at $\mathrm{pH} 7.4$, monitored by ThT fluorescence. Using hIAPP as a positive control, which is known for its fast aggregation propensity, ${ }^{58,61}$ we observed that both pramlintide and rIAPP aggregate weakly, as expected, ${ }^{15,62,63}$ due to the presence of the three proline residues in their primary sequence. ${ }^{15,64}$ Pramlintide aggregation is slightly attenuated by $\mathrm{Cu}^{2+}$, which confirms that $\mathrm{Cu}^{2+}$ changes the globular structure of the peptide. Analogous observations 
have been reported for $\mathrm{Cu}^{2+}$ binding to a monomeric fragment of hIAPP $(15-22),{ }^{64}$ but a contrary phenomenon was observed for $\mathrm{Zn}^{2+}$-pramlintide complexes, where the addition of metal strongly enhanced the precipitation. ${ }^{59}$ This was hypothesized to be caused by the formation of a macrochelate, involving His 18 imidazole and the $\mathrm{N}$-terminal amine in coordination. In the case of $\mathrm{Cu}^{2+}$, its binding either to the $\mathrm{N}$-terminus or to His 18 prevents the complex from aggregating. No influence of $\mathrm{Cu}^{2+}$ on rat amylin aggregation was detected, which leaves us with the conclusion that the binding of $\mathrm{Cu}^{2+}$ to the imidazole ring decreases the rate of aggregation to pramlintide with respect to rIAPP, most likely due to the fact that binding of $\mathrm{Cu}^{2+}$ to the imidazole of His 18 interrupts $\beta$-sheet formation, which is a crucial step for the initiation of the aggregation process.

In summary, the addition of copper(II) ions to pramlintide, the analogue of human amylin, prevents its aggregation, while the addition of this metal to rat amylin has no influence on its aggregation properties. Both peptides bind $\mathrm{Cu}(\mathrm{II})$ via the $\mathrm{N}$ terminal amino group and the adjacent amide nitrogens; the major difference in the $\mathrm{Cu}$ (II) binding mode comes from the absence of His 18 in the sequence of rat amylin, thus preventing the formation of the $\mathrm{Cu}(\mathrm{II})-\mathrm{His} 18$ bound form, observed in the case of the pramlintide complex. Moreover, Sinopoli et al. showed that the presence of copper(II) not only influences the aggregation properties of amylin analogues but also has a major influence on their cytotoxicity and their vulnerability to being degraded by proteases. ${ }^{65}$ Because the dyshomeostasis of $\mathrm{Cu}$ (II) seems to be involved in the development of type II diabetes, ${ }^{16}$ the differences in the aggregation properties of the two copper(II) complexes may have important implications in vivo. To make this picture even more complicated, one has to keep in mind the findings of Tomasello et al., who showed that the rat amylin-mediated $\beta$-cell toxicity can occur despite the absence of any amyloid forms. ${ }^{66}$ Further work, in collaboration with a group of biologists, is underway in our group.

\section{CONCLUSIONS}

The interactions of the studied amylin analogues, rat amylin and pramlintide, with $\mathrm{Cu}^{2+}$ result in conformational changes in these analogues. Certain differences in the primary sequence of these molecules affect the mode of coordination of these peptides with $\mathrm{Cu}^{2+}$. Rat amylin and pramlintide form stable and monomeric complexes with this metal, as proven by MS, NMR, CD, EPR, and UV-vis spectroscopies and potentiometric titrations. To the best of our knowledge, this is the first detailed study of this chemical phenomenon using this many different analytical methods. In both cases, the N-terminus of the peptides is directly involved in $\mathrm{Cu}^{2+}$ binding in solution (Figures 3 and 4). However, in the case of pramlintide, two species coexist together in solution: the one in which copper(II) is bound to the N-terminus and neighboring amides and the other in which the imidazole ring of His 18 and neighboring amides directed toward the $\mathrm{N}$-terminus are also involved in $\mathrm{Cu}^{2+}$ binding (Figure 5). Differences in the stabilities of $\mathrm{Cu}^{2+}$-rat amylin and $\mathrm{Cu}^{2+}$-pramlintide complexes are minor (as visualized by a competition plot in Figure S8).

These findings are in very good agreement with previously published data for a mutated $\mathrm{R} 18 \mathrm{H} \mathrm{Cu} \mathrm{Cu}^{2+}$-rat amylin complex $^{33}$ and with the results of studies of the hIAPP1-19 fragment bound to $\mathrm{Cu}^{2+}$.
Pramlintide aggregation is slightly attenuated by $\mathrm{Cu}^{2+}$, which confirms the impact of this metal on the globular structure of the peptide. Because no influence of $\mathrm{Cu}^{2+}$ on rat amylin aggregation was detected, we may hypothesize that the binding of $\mathrm{Cu}^{2+}$ to the imidazole ring decreases the rate of aggregation to pramlintide with respect to that of rat amylin. Most probably, the coordination of $\mathrm{Cu}^{2+}$ to His 18 imidazole interrupts $\beta$-sheet formation, which is one of the first steps of aggregation.

The findings outlined in this study on the coordination of $\mathrm{Cu}^{2+}$ with weakly aggregating analogues of amylin on the atomic level broaden our understanding of the behavior of amylin in terms of its structural properties in solution and aggregation properties upon interaction with the biologically relevant $\mathrm{Cu}^{2+}$ ion.

\section{ASSOCIATED CONTENT}

\section{Supporting Information}

The Supporting Information is available free of charge at https://pubs.acs.org/doi/10.1021/acs.inorgchem.9b03498.

Figures $\mathrm{S} 1-\mathrm{S} 8$ (PDF)

\section{AUTHOR INFORMATION}

\section{Corresponding Authors}

Mariusz Jaremko - Biological and Environmental Science and Engineering (BESE), King Abdullah University of Science and Technology (KAUST), 23955-6900 Thuwal, Saudi Arabia; Email: mariusz.jaremko@kaust.edu.sa

Magdalena Rowińska-Żyrek - Faculty of Chemistry, University of Wroclaw, 50383 Wroclaw, Poland; (o orcid.org/00000002-0425-1128; Email: magdalena.rowinska-zyrek@ chem.uni.wroc.pl

\section{Authors}

Mawadda Alghrably - Biological and Environmental Science and Engineering (BESE), King Abdullah University of Science and Technology (KAUST), 23955-6900 Thuwal, Saudi Arabia

Dorota Dudek - Faculty of Chemistry, University of Wroclaw, 50383 Wroclaw, Poland

Abdul-Hamid Emwas - Core Laboratories, King Abdullah University of Science and Technology (KAUST), 23955 Thuwal, Kingdom of Saudi Arabia

Łukasz Jaremko - Biological and Environmental Science and Engineering (BESE), King Abdullah University of Science and Technology (KAUST), 23955-6900 Thuwal, Saudi Arabia

Complete contact information is available at:

https://pubs.acs.org/10.1021/acs.inorgchem.9b03498

\section{Author Contributions}

${ }^{\|}$M.A. and D.D. contributed equally to this work.

\section{Notes}

The authors declare no competing financial interest.

\section{ACKNOWLEDGMENTS}

Financial support by the National Science Centre (UMO2017/26/A/ST5/00364, to M. R.-Ż.) is gratefully acknowledged. M.J., M.A., A.H.E., and $Ł$. J. would like to thank the King Abdullah University of Science and Technology (KAUST) for the financial support. 


\section{REFERENCES}

(1) Brender, J. R.; Lee, E. L.; Hartman, K.; Wong, P. T.; Ramamoorthy, A.; Steel, D. G.; Gafni, A. Biphasic effects of insulin on islet amyloid polypeptide membrane disruption. Biophys. J. 2011, 100 (3), 685-692.

(2) Fineman, M.; Koda, J.; Shen, L.; Strobel, S.; Maggs, D.; Weyer, C.; Kolterman, O. The human amylin analog, pramlintide, corrects postprandial hyperglucagonemia in patients with type 1 diabetes. Metab., Clin. Exp. 2002, 51 (5), 636-641.

(3) Weyer, C.; Maggs, D. G.; Young, A. A.; Kolterman, O. G. Amylin replacement with pramlintide as an adjunct to insulin therapy in type 1 and type 2 diabetes mellitus: a physiological approach toward improved metabolic control. Curr. Pharm. Des. 2001, 7 (14), 13531373.

(4) Banting, F. G.; Best, C. H. The internal secretion of the pancreas. Indian J. Med. Res. 2007, 125 (3), L251.

(5) Bliss, M. "Texts and Documents": Banting's, Best's, and Collip's Accounts of the Discovery of Insulin. Bull. Hist. Med. 1982, 56 (4), 554.

(6) Bliss, M. The discovery of insulin: the inside story. Publ. - Am. Inst. Hist. Pharm. 1997, 16, 93-99.

(7) Westermark, P.; Andersson, A.; Westermark, G. T. Islet amyloid polypeptide, islet amyloid, and diabetes mellitus. Physiol. Rev. 2011, 91 (3), 795-826.

(8) Hartman, K.; Brender, J. R.; Reid, K. R.; Smith, P. E.S.; Nanga, R. P.R.; Cavitt, M. A.; Lee, E. L.; Steel, D. G.; Gafni, A.; Kennedy, R. T.; Ramamoorthy, A. A single mutation in the non-amyloidogenic region of IAPP greatly reduces toxicity. Biophys. J. 2009, 96 (3), 92a.

(9) Phillips, L. K.; Horowitz, M. Amylin. Current Opinion in Endocrinology. Curr. Opin. Endocrinol. Diabetes 2006, 13 (2), 191198.

(10) Cao, P.; Abedini, A.; Raleigh, D. P. Aggregation of islet amyloid polypeptide: from physical chemistry to cell biology. Curr. Opin. Struct. Biol. 2013, 23 (1), 82-89.

(11) Pittner, R. A.; Albrandt, K.; Beaumont, K.; Gaeta, L. S.; Koda, J. E.; Moore, C. X.; Rittenhouse, J.; Rink, T. J. Molecular physiology of amylin. J. Cell. Biochem. 1994, 55 (S1994A), 19-28.

(12) Roth, J. D.; Mack, C. M.; Soares, C. J.; Ghosh, S. S.; Parkes, D. G. Amylin-based pharmacotherapy-past, present \& future. Immunol., Endocr. Metab. Agents Med. Chem. 2008, 8 (4), 317-324.

(13) Ryan, G. J.; Jobe, L. J.; Martin, R. Pramlintide in the treatment of type 1 and type 2 diabetes mellitus. Clin. Ther. 2005, 27 (10), $1500-1512$.

(14) Wang, L.; Liu, Q.; Chen, J. C.; Cui, Y. X.; Zhou, B.; Chen, Y. X.; Zhao, Y. F.; Li, Y. M. Antimicrobial activity of human islet amyloid polypeptides: an insight into amyloid peptides' connection with antimicrobial peptides. Biol. Chem. 2012, 393 (7), 641-6.

(15) Westermark, P.; Engström, U.; Johnson, K. H.; Westermark, G. T.; Betsholtz, C. Islet amyloid polypeptide: pinpointing amino acid residues linked to amyloid fibril formation. Proc. Natl. Acad. Sci. U. S. A. 1990, 87 (13), 5036-5040.

(16) Tanaka, A.; Kaneto, H.; Miyatsuka, T.; Yamamoto, K.; Yoshiuchi, K.; Yamasaki, Y.; Shimomura, I.; Matsuoka, T. A.; Matsuhisa, M. Role of copper ion in the pathogenesis of type 2 diabetes. Endocr. J. 2009, 56 (5), 699-706.

(17) Brender, J. R.; Hartman, K.; Nanga, R. P.; Popovych, N.; de la Salud Bea, R.; Vivekanandan, S.; Marsh, E. N.; Ramamoorthy, A. J. Am. Chem. Soc. 2010, 132, 8973.

(18) Lemaire, K.; Ravier, M. A.; Schraenen, A.; Creemers, J. W. M.; Van de Plas, R.; Granvik, M.; Van Lommel, L.; Waelkens, E.; Chimienti, F.; Rutter, G. A.; Gilon, P.; Veld, P.; Schuit, F. C. Proc. Natl. Acad. Sci. U. S. A. 2009, 106, 14872-7.

(19) Masad, A.; Hayes, L.; Tabner, B. J.; Turnbull, S.; Cooper, L. J.; Fullwood, N. J.; German, M. J.; Kametani, F.; El-Agnaf, O. M.; Allsop, D. Copper-mediated formation of hydrogen peroxide from the amylin peptide: a novel mechanism for degeneration of islet cells in type-2 diabetes mellitus? FEBS Lett. 2007, 581 (18), 3489-93.

(20) Exley, C.; House, E.; Patel, T.; Wu, L.; Fraser, P. E. J. Inorg. Biochem. 2010, 104 (10), 1125-1129.
(21) Ward, B.; Walker, K.; Exley, C. Copper (II) inhibits the formation of amylin amyloid in vitro. J. Inorg. Biochem. 2008, 102 (2), $371-375$.

(22) Alghrably, M.; Czaban, I.; Jaremko, L.; Jaremko, M. Interaction of amylin species with transition metals and membranes. J. Inorg. Biochem. 2019, 191, 69-76.

(23) Yu, Y. P.; Lei, P.; Hu, J.; Wu, W. H.; Zhao, Y. F.; Li, Y. M. Copper-induced cytotoxicity: reactive oxygen species or islet amyloid polypeptide oligomer formation. Chem. Commun. (Cambridge, U. K.) 2010, 46 (37), 6909-11.

(24) Ma, L.; Li, X.; Wang, Y.; Zheng, W.; Chen, T. Cu(II) inhibits hIAPP fibrillation and promotes hIAPP-induced beta cell apoptosis through induction of ROS-mediated mitochondrial dysfunction. $J$. Inorg. Biochem. 2014, 140, 143-52.

(25) Poulson, B. G.; Szczepski, K.; Lachowicz, J. I.; Jaremko, L.; Emwas, A.-H.; Jaremko, M. Aggregation of biologically important peptides and proteins: inhibition or acceleration depending on protein and metal ion concentrations. RSC Adv. 2020, 10, 215.

(26) Nimse, S. B.; Pal, D. Free radicals, natural antioxidants, and their reaction mechanisms. RSC Adv. 2015, 5 (35), 27986-28006.

(27) Li, H.; Ha, E.; Donaldson, R. P.; Jeremic, A. M.; Vertes, A. Rapid Assessment of Human Amylin Aggregation and Its Inhibition by Copper(II) Ions by Laser Ablation Electrospray Ionization Mass Spectrometry with Ion Mobility Separation. Anal. Chem. 2015, 87 (19), 9829-9837.

(28) Emwas, A. H. M.; Al-Talla, Z. A.; Guo, X. R.; Al-Ghamdi, S.; Al-Masri, H. T. Utilizing NMR and EPR spectroscopy to probe the role of copper in prion diseases. Magn. Reson. Chem. 2013, 51 (5), $255-268$.

(29) Kallay, C.; David, A.; Timari, S.; Nagy, E. M.; Sanna, D.; Garribba, E.; Micera, G.; De Bona, P.; Pappalardo, G.; Rizzarelli, E.; Sovago, I. Copper(II) complexes of rat amylin fragments. Dalton Trans. 2011, 40 (38), 9711-9721.

(30) Alahmari, F.; Davaasuren, B.; Emwas, A.-H.; Costa, P. M.; Rothenberger, A. Tris(ethylenediamine)nickel(II) thio-hydroxogermanate monohydrate: Synthesis, crystal structure, $1 \mathrm{H}$ NMR, EPR, optical and magnetic properties. Inorg. Chim. Acta 2019, 488, 145151.

(31) Dávid, Á.; Kállay, C.; Sanna, D.; Lihi, N.; Sóvágó, I.; Várnagy, K. Potentiometric and spectroscopic studies on the copper (II) complexes of rat amylin fragments. The anchoring ability of specific non-coordinating side chains. Dalton Transactions 2015, 44 (39), 17091-17099.

(32) Sánchez-López, C.; Cortés-Mejía, R.; Miotto, M. C.; Binolfi, A.; Fernández, C. O.; Del Campo, J. M.; Quintanar, L. Copper coordination features of human islet amyloid polypeptide: the type 2 diabetes peptide. Inorg. Chem. 2016, 55 (20), 10727-10740.

(33) Rowińska-Żyrek, M. Coordination of $\mathrm{Zn} 2+$ and $\mathrm{Cu} 2+$ to the membrane disrupting fragment of amylin. Dalton Transactions 2016, 45 (19), 8099-8106.

(34) Magrì, A.; Pietropaolo, A.; Tabbì, G.; La Mendola, D.; Rizzarelli, E. From peptide fragments to whole protein: copper (II) load and coordination features of IAPP. Chem. - Eur. J. 2017, 23 (71), $17898-17902$.

(35) Gran, G.; Dahlenborg, H.; Laurell, S.; Rottenberg, M. Determination of the equivalent point in potentiometric titrations. Acta Chem. Scand. 1950, 4 (4), 559-577.

(36) Gans, P.; Sabatini, A.; Vacca, A. SUPERQUAD: an improved general program for computation of formation constants from potentiometric data. J. Chem. Soc., Dalton Trans. 1985, No. 6, $1195-1200$

(37) Gans, P.; Sabatini, A.; Vacca, A. Investigation of equilibria in solution. Determination of equilibrium constants with the HYPERQUAD suite of programs. Talanta 1996, 43 (10), 1739-1753.

(38) Alderighi, L.; Gans, P.; Ienco, A.; Peters, D.; Sabatini, A.; Vacca, A. Hyperquad simulation and speciation (HySS): a utility program for the investigation of equilibria involving soluble and partially soluble species. Coord. Chem. Rev. 1999, 184 (1), 311-318. 
(39) Covington, A. K.; Paabo, M.; Robinson, R. A.; Bates, R. G. Use of the glass electrode in deuterium oxide and the relation between the standardized $\mathrm{pD}(\mathrm{paD})$ scale and the operational $\mathrm{pH}$ in heavy water. Anal. Chem. 1968, 40 (4), 700-706.

(40) Delaglio, F.; Grzesiek, S.; Vuister, G. W.; Zhu, G.; Pfeifer, J.; Bax, A. NMRPipe: a multidimensional spectral processing system based on UNIX pipes. J. Biomol. NMR 1995, 6 (3), 277-293.

(41) Goddard, T.; Kneller, D. Sparky 3; University of California, San Francisco: San Francisco, 2008.

(42) Wüthrich, K. NMR with proteins and nucleic acids. Europhys. News 1986, 17 (1), 11-13.

(43) Brasuń, J.; Cebrat, M.; Jaremko, Ł.; Jaremko, M.; Ilc, G.; Gładysz, O.; Zhukov, I. The structural effects of the Cys-SS-Cys bridge exchange by the His-Cu (II)-His motif studied on natural peptides-a promising tool for natural compounds-based design. Dalton Transactions 2009, No. 25, 4853-4857.

(44) Haque, M. A.; Gandi, A. N.; Mohanraman, R.; Weng, Y. K.; Davaasuren, B.; Emwas, A. H.; Combe, C.; Baran, D.; Rothenberger, A.; Schwingenschlogl, U.; Alshareef, H. N.; Dong, S.; Wu, T. A OD Lead-Free Hybrid Crystal with Ultralow Thermal Conductivity. Adv. Funct. Mater. 2019, 29 (13), 1809166.

(45) Liang, H. F.; Xia, C.; Emwas, A. H.; Anjum, D. H.; Miao, X. H.; Alshareef, H. N. Phosphine plasma activation of alpha-Fe2O3 for high energy asymmetric supercapacitors. Nano Energy 2018, 49, 155-162. (46) Astashkin, A. V.; Nesmelov, Y. E. Mn2+-Nucleotide Coordination at the Myosin Active Site As Detected by Pulsed Electron Paramagnetic Resonance. J. Phys. Chem. B 2012, 116 (46), 13655-13662.

(47) Cammack, R. EPR Spectra of Transition-Metal Proteins: the Benefits of Data Deposition in Standard Formats. Appl. Magn. Reson. 2010, 37 (1-4), 257-266.

(48) Drew, S. C.; Barnham, K. J. The Heterogeneous Nature of $\mathrm{Cu} 2+$ Interactions with Alzheimer's Amyloid-beta Peptide. Acc. Chem. Res. 2011, 44 (11), 1146-1155.

(49) Zoleo, A.; Contessi, S.; Lippe, G.; Pinato, L.; Brustolon, M.; Brunel, L. C.; Dabbeni-Sala, F.; Maniero, A. L. High-affinity metalbinding site in beef heart mitochondrial F(1)ATPase: An EPR spectroscopy study. Biochemistry 2004, 43 (41), 13214-13224.

(50) Mattar, S. M.; Emwas, A. H. A tuneable doubly stacked dielectric resonator housed in an intact TE102 cavity for electron paramagnetic resonance spectroscopy. Chem. Phys. Lett. 2003, 368 (5-6), 724-731.

(51) Mattar, S. M.; Emwas, A. H.; Calhoun, L. A. Spectroscopic studies of the intermediates in the conversion of 1,4,11,12-tetrahydro9,10-anthraquinone to 9,10-anthraquinone by reaction with oxygen under basic conditions. J. Phys. Chem. A 2004, 108 (52), 1154511553.

(52) Mattar, S. M.; Emwas, A. H.; Stephens, A. D. Accurate computations of the methyl isotropic hyperfine coupling constants in 2-methyl-1,4-benzosemiquinone radical intermediate. Chem. Phys. Lett. 2002, 363 (1-2), 152-160.

(53) Mattar, S. M.; Stephens, A. D.; Emwas, A. H. Generation and spectroscopic characterization of the 2,3,5,6-tetramethoxy-1,4-benzosemiquinone reactive intermediate. Chem. Phys. Lett. 2002, 352 (12), 39-47.

(54) Besson, E.; Gastaldi, S.; Bloch, E.; Zielonka, J.; Zielonka, M.; Kalyanaraman, B.; Aslan, S.; Karoui, H.; Rockenbauer, A.; Ouari, O.; Hardy, M. Embedding cyclic nitrone in mesoporous silica particles for EPR spin trapping of superoxide and other radicals. Analyst 2019, 144 (14), 4194-4203.

(55) Sahli, F.; Godard, A.; Vileno, B.; Lepoittevin, J. P.; GimenezArnau, E. Formation of methyl radicals derived from cumene hydroperoxide in reconstructed human epidermis: an EPR spin trapping confirmation by using C-13-substitution. Free Radical Res. 2019, 53 (7), 737-747.

(56) Toybenshlak, M.; Carmieli, R. A New and Robust Method for In-situ EPR Electrochemistry. Isr. J. Chem. 2019, 59, 1020-1026.
(57) Jha, S.; Snell, J. M.; Sheftic, S. R.; Patil, S. M.; Daniels, S. B.; Kolling, F. W.; Alexandrescu, A. T. $\mathrm{pH}$ dependence of amylin fibrillization. Biochemistry 2014, 53 (2), 300-310.

(58) da Silva, D. C.; Fontes, G. N.; Erthal, L. C.; Lima, L. M. T. Amyloidogenesis of the amylin analogue pramlintide. Biophys. Chem. 2016, 219, 1-8.

(59) Erthal, L. C.; Marques, A. F.; Almeida, F. C.; Melo, G. L.; Carvalho, C. M.; Palmieri, L. C.; Cabral, K. M.; Fontes, G. N.; Lima, L. M. T. Regulation of the assembly and amyloid aggregation of murine amylin by zinc. Biophys. Chem. 2016, 218, 58-70.

(60) Łoboda, D.; Rowińska-Żyrek, M. Zn (II)-pramlintide: Stability, binding sites and unexpected aggregation. J. Inorg. Biochem. 2017, 174, $150-155$.

(61) Reddy, A. S.; Wang, L.; Singh, S.; Ling, Y. L.; Buchanan, L.; Zanni, M. T.; Skinner, J. L.; De Pablo, J. J. Stable and metastable states of human amylin in solution. Biophys. J. 2010, 99 (7), 22082216.

(62) Nonoyama, A.; Laurence, J. S.; Garriques, L.; Qi, H.; Le, T.; Middaugh, C. R. A biophysical characterization of the peptide drug pramlintide (AC137) using empirical phase diagrams. J. Pharm. Sci. 2008, 97 (7), 2552-2567.

(63) Betsholtz, C.; Christmanson, L.; Engström, U.; Rorsman, F.; Jordan, K.; O’Brien, T. D.; Murtaugh, M.; Johnson, K. H.; Westermark, P. Structure of cat islet amyloid polypeptide and identification of amino acid residues of potential significance for islet amyloid formation. Diabetes 1990, 39 (1), 118-122.

(64) Moriarty, D. F.; Raleigh, D. P. Effects of sequential proline substitutions on amyloid formation by human amylin20-29. Biochemistry 1999, 38 (6), 1811-1818.

(65) Sinopoli, A.; Magrì, A.; Milardi, D.; Pappalardo, M.; Pucci, P.; Flagiello, A.; Titman, J. J.; Nicoletti, V. G.; Caruso, G.; Pappalardo, G.; Grasso, G. The role of copper(II) in the aggregation of human amylin. Metallomics 2014, 6, 1841-1852.

(66) Tomasello, M. F.; Sinopoli, A.; Attanasio, F.; Giuffrida, M. L.; Campagna, T.; Milardi, D.; Pappalardo, G. Molecular and cytotoxic properties of hIAPP17-29 and rIAPP17-29 fragments: a comparative study with the respective full-length parent polypeptides. Eur. J. Med. Chem. 2014, 81, 442-55. 